\title{
Sınıf Öğretmeni Adaylarının Eğitim Teknolojisi Kavramına İlişkin Metaforik Algıları ${ }^{12}$
}

\section{Esma KURU}

Dr. Öğr. Üyesi, Kahramanmaraş Sütçü İmam Üniversitesi, Eğitim Fakültesi, Türkçe ve Sosyal Bilimler Eğitimi Bölümü

esmkuru@gmail.com

\section{Oğuzhan KURU}

Dr. Öğr. Üyesi, Kahramanmaraş Sütçü İmam Üniversitesi, Eğitim Fakültesi, Temel Eğitim Bölümü, Kahramanmaraş

okuru82@hotmail.com

\section{Özet}

$\mathrm{Bu}$ araştırmada eğitim fakültesinde farklı sınıf düzeylerinde öğrenim gören sınıf öğretmenliği öğrencilerinin "eğitim teknolojisi" kavramına yönelik algıları tespit edilip değerlendirilmiştir. Araştırmanın amacı, insan yaşamının daha verimli hale getirilmesi adına eğitim - öğretim hayatı için önemli olarak görülen "eğitim teknolojisi” kavramının pratikte nasıl bir anlam ifade ettiğini, öğrenciler tarafından metaforik olarak nasıl algılandığını tespit etmektir. Sınıf öğretmeni adaylarının "eğitim teknolojisi" kavramına ilişkin metaforik algılarının belirlenmeye çalışıldığı bu çalışmada nitel araştırma desenlerinden olgu bilim deseni kullanılmıştır. Araştırmanın çalışma grubunu 2017-2018 eğitim öğretim yılında Kahramanmaraş Sütçü İmam Üniversitesi Eğitim Fakültesinde öğrenim gören sınıf öğretmenliği öğrencileri oluşturmaktadır. Çalışma grubu amaçlı örnekleme yöntemi ile seçilmiş 2., 3., ve 4. sınıf 153 sinıf öğretmenliği öğrencisinden oluşmaktadır. Araştırmada veriler araştırmacı tarafından hazırlanmış "Eğitim Teknolojisi... gibidir, çünkü..." sorusunu içeren eksik bırakılmış cümleden oluşan bir form yardımıyla elde edilmiş̧ir. Araştırmanın sonuçlarına göre katılımcılar tarafindan birbirinden farklı 102metafor üretildiği görülmüştür. Metaforlar anlamsal açıdan birbirlerine olan benzerliklerine göre kategorilere ayrılarak 7 olumlu anlam içeren kategori oluşturulmuştur. Üretilen 46 metafor ile en fazla metafor sayısina sahip olan kategori "Temel gereksinimin sembolü olarak eğitim teknolojisi" kategorisidir ( $\mathrm{f}=74)$. Kategori bünyesinde en fazla değinilen Metaforlar ise "su", "güneş", "kitap", "beyin" metaforu olmuştur. En az metaforun üretildiği ve en az öğrenci sayısına sahip $(\mathrm{f}=7)$ kategori ise "Gelişimin sembolü olarak eğitim teknolojisi" kategorisi

\footnotetext{
${ }^{1} \mathrm{Bu}$ çalışmanın bir kısmı II. Uluslararası Eğitim ve Araştırmaları Sempozyumunda sözlü bildiri olarak sunulmuştur. 26-28 Nisan 2018, Türkiye

${ }^{2}$ Makale Geliş/Kabul Tarihi:10.07.18/17.12.18
} 
olarak belirlenmiştir. Sınıf öğretmeni adaylarının eğitim teknolojisi kavramına ilişkin olumlu bir algıya sahip oldukları ve kavrama ilişkin olarak olumsuz bir metafor üretmedikleri sonucuna ulaşılmıştır.

Anahtar Kelimeler: Metafor, Eğitim Teknolojisi, Öğretmen Adayı, Sınıf Öğretmeni Aday1

\title{
The Metaphorical Perceptions of Classroom Teacher Candidates of the Concept of Education Technology
}

\begin{abstract}
In this study, the perceptions of classroom teacher students who are receiving education in different grade levels at the faculty of education of the concept of 'education technology' has been identified and evaluated. The purpose of the study is to determine what 'education technology,' which is regarded as important in education-training life in terms of making human life more productive, means in practice and how it is perceived metaphorically by the students. In this study, in which the metaphorical perceptions of classroom teacher candidates of the concept of 'education technology' has been attempted to be determined, the phenomenology design which is one of the qualitative research designs has been used. The study group of the study consists of classroom teacher students who are receiving education at the Faculty of Education of Kahramanmaraş Sütçü İmam University in the 2017-2018 academic year. The study group consists of 153 classroom teacher students from the junior, sophomore and senior years who were selected through the purposeful sampling method. The data in the study was obtained through the form which was prepared by the researcher and consisted of the question "Education Technology is like............, because......" which was left incomplete. According to the results of the study, it was observed that the participants produced 102 different metaphors. The metaphors were separated into different categories in terms of their similarities in meaning and 7 categories which involve positive meanings were created. The category with the highest amount of metaphors with 46 metaphors was "Education technology as the symbol of basic need" ( $\mathrm{f}=74)$. The most frequently mentioned metaphors in the categories have been 'water,' 'the sun,' 'book' and 'brain.' The category in which the least amount of metaphors were produced and contained the least amount of students $(f=7)$ was determined as the "Education technology as the symbol of development" category. It has been concluded that the classroom teacher students have a positive perception of the concept of education technology and have not created a negative metaphor related to the concept.
\end{abstract}

Keywords: Metaphor, Education Technology, Teacher Candidate, Classroom Teacher Candidate 


\section{GíRiş}

İnsanlar dilek ve temennilerini aktarmak için benzetmelerden, farklı konuları birbiriyle ilişkilendirici jestler gibi çeşitli iletişim yollarından yararlanmaktadır. Kullandıkları bu yollar aracılığıyla kişiler anlatılmak istenenleri hem etkileyici bir şekilde hem de daha kalıcı ve basit bir şekilde diğer kişilere anlatırlar. Anlatımı kolaylaştırmak, bilinen bir durumdan hareketle bilinmeyen bir durumun anlaşılmasını sağlamak adına kullanılan iletişim yollarından biri de metafordur (Ünsal, Korkmaz ve Çetin, 2016). Antik çağlardaki retorikten günümüze kadar felsefe, dilbilim, anlambilim, eğitim, psikoloji gibi farklı alanlarda incelenen bir konu olan "metafor" kelimesi Yunanca değişmek anlamına gelen "metopherein-meta" ve dayanmak anlamına gelen "pherein" kelimelerinden türemiştir. Bir kavramı, olguyu, ifade ettiği anlamdan öteye taşımak, ifade ettiği anlamdan daha fazlasını yükleyerek metaforu değişim taşıyıcı bir araç olarak kullanma fikri bilinenlerin yeni anlayışlara, yeni yorumlamalara dönüştürülmelerine yardımcı olmaktadır (Levine, 2005; Uyan Dur, 2016). Birçok kavram soyut olduğu ya da tecrübeler ile yer edinemediği için, onları açık terimlerle algılanan başka kavramlar vasitasıyla anlamaya, öğrenmeye ihtiyaç duyulmaktadır. Duyulan bu ihtiyaç kavram sisteminde metaforik tanımlamaya yol açmaktadır (Parın, 2017).

Kavramları algılarken çoğu zaman başka bir kavramla olan ortak yönleri akı1lara getirilir. Bir kavramın yeni öğrenilen başka bir özelliği çoğu zaman çok iyi bilinen başka durumların özellikleriyle eşleştirilir ya da zihinlerde benzetmeler oluşturulur. $\mathrm{Bu}$ sebepledir ki; metaforlar anlaşılması zor kavramların benzetme yoluyla bilinen kavramlarla anlatılması olarak formel ve informel öğrenmelerde karşımıza çıkmaktadır (Geçit ve Gencer, 2011). Metafor, bir kavramın bireyde oluşturduğu etiket, anlam ya da kavramsal ifadelerdir. Bir görme ve anlama sürecidir. Bir bireyin yüksek düzeyde soyut, karmaşık veya kuramsal bir olguyu anlamasına ve açılamasına yardımcı olan, bir kavram, olgu ya da olayın başka bir kavram, olgu ya da olaya olan benzerliklerinden yararlanarak açıklanmasını sağlayan güçlü zihinsel bir araç olarak değerlendirilmektedir. Bireylerin basit olarak bir kavramı bir başka kavramla açıklamasından daha önemli ve güçlü bir zihinsel üretimdir. Çünkü ilgili kavrama dönük sahip olunan derinliği ve deneyimleri ifade etmektedir (Oxford, Tomlinson ve Lonhini, 1998; Erarslan, 2011; Erdemir, Bakırcı ve Eyduran, 2009). Metaforlar, dilin zenginleşmesini sağlayan ve ona çeşitlilik katan,bireyin bir kavramı ya da olguyu algıladığı biçimde benzetmelerden, sembollerden yararlanarak ifade etmesidir. Yaşantılarımızı nasıl sürdüreceğimizle ilgili bize yardımcı olan, kılavuzluk ederek gelecekteki eylemlerimize yön veren, sıklıkla başvurduğumuz, yararlandığımız hayatımızın olmazsa olmaz ifadeleridir (Wulf ve Dudis, 2005; Aydın, 2010; Aydın, 2011; 
Parın, 2017). Metaforlar, insanların dünyayı, hayatı, çevreyi, olayları ve nesneleri nasıl gördüklerini açılamaya çalışırken kullandıkları araçlardır. Temel kavramlarımızın çoğu mekansallaştırma metaforları ile düzenlenmiştir. $\mathrm{Bu}$ nedenle dünyayı algılama ve anlamlandırma açısından metaforlar bireylerin kendilerine özgü birer zihinsel haritalama ve modelleme aracıdır (Lakoff ve Johnson, 2003; Cerit, 2008). Farklı benzetmelerden yararlanarak yapılan anlamlandırma işlemi, yani metafor kullanımı, kişilerin bilinmeyeni bilinenle ilişkilendirerek kavramlar arasında yeni bağlantılar kurmaya çalışmasıyla yaratıcılığı geliştirmektedir (Aydoğdu, 2008: 27).

Bilimsel bir söylemden ziyade söz bilim ifadesi olan ve eğitim öğretim sürecinde sıklıkla kullanılan metaforlar, eğitim öğretim faaliyetlerinde öğretmen ve öğrenci arasında kullanılan dilin ifadesi olup; sınıfta derslerin daha etkili ve verimli geçmesini sağlayan, öğrenmede önemli bir öğrenme aracı olan zihinsel imgelerdir. Derse olan ilginin, farkındalı̆̆ın arttırılmasını sağlayarak hızlı öğrenmelerin gerçekleştirilmesine, bilginin somutlaştırılarak eğitim-öğretim faaliyetlerinin etkili bir biçimde gerçekleşmesine, hedeflere ulaşılmasına yardımcı olan güçlü ve sihirli bir araç olarak düşünülmektedir (Ortony, 1993; Kıral, 2015). Öğretim faaliyetlerinde öğretmenler uygulamaları yönlendirmek ve öğretim rollerini kavramsallaştırmak için metaforlardan yararlanmaktadır (Tobin ve Ulerick'ten aktaran Stofflett, 1996). Yapılan kavramsallaştırmalar, öğretmenlerin inançları anlamalarına yardımcı olmakta ve daha sonraki uygulamaları geliştirebilecek yansıtmaları da teşvik edici bir rol üstlenmektedir (Tobin'den aktaran Stofflett, 1996). Bu sebeple eğitim öğretim sürecinde metaforlara başvurulmakta, öğretim sürecini somutlaştırarak anlamlandırmada metaforlardan yararlanılmaktadır. Fakat öğretmenlerin öğretim sürecinde yararlandıkları metaforların önemi sadece öğretilecek konunun somutlaştırılması ile sınırlı değildir. Öğretmenlerin kullandıkları metaforlar, kendilerini nasıl gördüklerini, çevrelerini, çevrelerindeki süreç ve yapıları nasıl algıladıklarını da göstermektedir (Tobin ve Ulerick'ten aktaran Stofflett, 1996; Windschitl, 2002).

Küresel dünyada ayakta kalabilmek için toplumların ve bireylerin gelişimi, değişimi ve dönüşümü anlayıp, onu kontrol altına alabilme ve yönlendirebilme kapasiteleri ülkeler arasındaki gelişmişlik düzeylerini belirleyen unsurlardır (Topçu ve Türk, 2016). Teknolojik gücü kullanabilme gelişmişlik düzeyinin göstergesi durumundadır. Bilgi çağında yeni bilgi üretimi ile birlikte teknolojinin gücü artmakta ve sonuç olarak teknoloji hayatımızın her aşamasında vazgeçilmez bir hal almaktadır. Teknolojinin ilerlemesiyle birlikte her alanda hızlı bir değişim, gelişim yaşanmaktadır. Her şeyin böylesine değiştiği dünyada eğitimin bu gelişmelerden etkilenmemesi mümkün değildir. Sanayi, sağlik başta olmak üzere tüm sektörlerde olduğu gibi eğitimde de teknolojinin gücünden faydalanılmakta, değişimler, yenileşmeler yaşanmaktadır 
(Flanagan ve Jacobsen'den aktaran F, Karadeniz ve Dalgıç, 2011). Teknoloji her alanın ihtiyaç duyduğu vazgeçilmezi olduğu kadar eğitim alanında da ihtiyaç duyulan, yararlanılan zaruri bir öğe haline gelmiştir. Çağımızda toplumsal değişme ve gelişmeleri başlatan, yönlendiren bir kurum olarak eğitim kurumlarının teknolojik gelişmeleri izlemek, bu teknolojileri kullanmak ve teknoloji kullanımının önemini öğretme zorunluluğu doğmuştur (Seferoğlu, 2009). Eğitim ve teknoloji kavramları arasındaki ciddi etkileşim kavramların iç içe girmiş kavramlar haline gelmesini sağlayarak "eğitim teknoloji" kavramını doğurmuştur. Eğitim teknolojisi; genelde eğitime özelde öğrenme durumlarına egemen olma adına bilgi ve becerilerden yararlanarak öğrenme ya da eğitim süreçlerinin yapısallaştırılması, sağlıklı ve kaliteli bir öğrenme- öğretme sürecinin tasarımı, uygulanması ve de geliştirilmesidir. Eğitim Teknolojisi, "insanın öğrenmesi" olgusunun tüm yönleri ile ilgili problemlerini sistematik bir biçimde analiz etmek ve bu problemlere çözüm bulma adına ilgili tüm unsurlardan (insan gücü, bilgiler, yöntemler, teknikler, araç gereçler vs) yararlanarak uygun tasarımlar, geliştirme, uygulama, değerlendirme sürecidir (Yanpar, 2007; Alkan, 2011; Şimşek, Becit, Özdamar vd., 2008).

Teknolojide yaşanan gelişmelerin hayatın her alanında olduğu gibi, öğrenme-öğretme süreçlerini de etkilemesi kaçınılmazdır. Günümüzde okullardan beklenen de bilgiye ulaşma ve onu etkili bir şekilde kullanma becerileriyle donatılmış, teknolojiyi kullanabilen, eğitim teknolojisinin farkında olan bireyler yetiştirmeleridir (Seferoğlu, 2009). Önem arz eden ve ilerleyen süreçte de önemini koruyacak olan konu ile ilgili olarak öğretmenlerin ve geleceğin öğretmenleri olacak öğretmen adaylarının meslek hayatlarında istenilen başarıya ulaşabilmeleri için teknolojinin eğitimdeki rolünü kabullenmeleri ve kullanma becerisine sahip olmaları gerekmektedir (Erdemir, Bakırcı ve Eyduran, 2009). Çünkü öğretmenlerin öğrenme ve öğretme sürecine iliş̧kin sergilemiş oldukları tutum ve davranışlar sınıf iklimine yansımaktadır. Öğretmenler, öğrenme ve öğretim ile ilgili görüşlerini farkında olmadan, kullandıkları metaforlar ile ifade ederler. Metaforlar öğretmenlerin kendi uygulamalarını anlama ve açıklama gücünü etkili bir biçimde kullanmalarına yardımc1 araçlardır (Semerci, 2007). Öğretmenlerin kullanmış oldukları metaforlarda öğrenme ve öğretme ile ilgili düşüncelerini yansıtmaktadır (Seung, Park ve Narayan, 2011; Kara ve Uysal 2015; Öksüz, Demir ve İci, 2016).Geleceğin öğretmenleri olacak öğretmen adaylarının eğitim teknolojisi kavramına yönelik algılarının sınıf iklimine yansıyacağı dolayısı ile öğrenme ortamına ve de öğrencilerin öğrenme durumlarına etki edeceği düşünüldüğünde "eğitim teknolojisi" kavramının pratikteki anlamsal ifadesinin belirlenmesinin önemli olduğunu söyleyebiliriz. Eğitim teknolojisinin ve eğitimde teknolojiden sağlıklı şekilde yararlanmanın bahsedilen önemi düşünüldüğünde öğretmen 
adaylarının bu kavrama yönelik metaforlarının belirlenmesinin alana yönelik katkı sağlayacağı öngörülmektedir.

\section{Araştırmanın Amacı}

Sınıf öğretmeni adaylarının eğitim teknolojisi kavramına yönelik algılarının belirlenmesinin önemli olduğu düşünülerek yürütülen araştırmanın amacı, sınıf öğretmeni adaylarının "eğitim teknolojisi" kavramına ilişkin metaforlarını belirlemektir. Belirtilen amaç dâhilinde aşağıdaki sorulara cevap aranmıştır:

- Sınıf öğretmen adaylarının "eğitim teknolojisi” kavramına ilişkin sahip oldukları metaforlar nelerdir?

- Eğitim teknolojisi kavramına yönelik metaforlar hangi kavramsal kategoriler bünyesinde toplanabilir?

\section{YÖNTEM}

Öğretmen adaylarının “eğitim teknolojisi” kavramına yönelik metaforik algılarının belirlenmeye çalışıldığ olgu bilim deseni kullanılmıştır. Olgubilim deseni farkında olduğumuz ancak derinlemesine ve ayrıntılı bir anlayışa sahip olmadığımız olgulara odaklanmaktadır. Bize tümüyle yabancı olmayan aynı zamanda da tam anlamıyla kavrayamadığımız olguları araştırmak için kullanılan nitel bir araştırma desenidir (Yıldırım ve Şimşek, 2008:72). Olgubilim deseninin esas amacı, bireylerin bir olguya ilişkin yaşantılarını, algılarını ve bunlara yüklediği anlamları ortaya çıkarmaktır (Erarslan, 2011).

\section{Çalışma Grubu}

Araştırmanın çalışma grubunu 2017-2018 eğitim öğretim y1lı bahar yarıyılında Kahramanmaraş Sütçü İmam Üniversitesinde 2.,3., 4.sınıfta öğrenim gören öğretim teknolojileri ve materyal tasarımı dersini almış olan 153 sinıf öğretmeni adayı oluşturmaktadır. Çalışma grubu seçilirken amaçlı örnekleme yöntemi kullanılmıştır. Amaçlı örnekleme; çalışmanın amacına bağlı olarak, bilgi açısından zengin durumların seçilerek derinlemesine çalışma yapmaya olanak tanıyan örneklemedir (Büyüköztürk, Çakmak, Akgün, Karadeniz ve Demirel, 2014: 90).

\section{Veri toplama Aracı ve Veri Toplama Süreci}

Araştırmanın verileri öğretmen adaylarının "eğitim teknolojisi" kavramına yönelik algılarını belirlenmek için araştırmacı tarafindan hazırlanan form ile 
elde edilmiştir. Form öğretmen adaylarının teknoloji kavramı ile metaforik olarak ilişki kurabilmesi ve verilen metaforun açıklanabilmesi adınaiki aşamadan oluşmaktadır. "Eğitim Teknolojisi.... gibidir, çünkü......". Metaforların araştırma aracı olarak kullanılmış olduğu çalışmalarda "gibi" kelimesi metaforun kaynağı ve metaforun konusu arasındaki ilişkiyi akla getirmek için, "çünkü" kelimesi ise araştırmanın katılımcılarının ürettikleri metaforlara mantıksal bir gerekçe sunmaları için kullanılmıştır (Saban, 2009). Hazırlanan formun öğretmen adaylarına dağıtılmasından önce metafor kavramının ne olduğu ile ilgili olarak bilgiler verilmiş, formun anlaşılması adına örneklerde bulunulmuş ve daha sonra öğretmen adaylarına 15-20 dk süre verilerek dağıtılan formda yer alan kavram ile ilgili olarak algılarını, benzetmelerini içeren metaforlarını oluşturmaları istenmiştir. Öğretmen adayları verilen süre dâhilinde formları doldurmuş ve doldurulan formlar araştırmacı tarafindan toplanmıştır.

\section{Verilerin Analizi}

Sınıf öğretmenliği öğrencilerinin eğitim teknolojisi kavramına yönelik metaforik algılarının belirlenmeye çalışıldığ içerik analizi ile analiz edilmiştir. İçerik analizi, özetlenen ve yorumlanan verilerin daha derin bir işleme tabi tutularak betimsel bir yaklaşımla fark edilmeyen kavram ve temaların okuyucunun anlayacağı bir biçimde düzenlenip yorumlandığı analiz tekniğidir (Yıldırım ve Şimşek, 2008).

Analizin ilk aşamasında öğretmen adayları tarafından üretilen metaforlar incelenmiş, incelenen metaforlar arasında çalışmaya uygun bulunmayan metaforlar elenmiş, çalışmaya uygun olanlar ise anlamsal açıdan benzerliklerine göre gruplandırılmış, numaralandırılmış “Ö1, Ö2, Ö3,...”ş̧eklinde kodlanmıştır. Yapılan literatür taramaları ile birlikte benzer çalışmalar incelenmiş, uzman görüşlerine başvurulmuş ve anlamsal açıdan belirlenen ortak özellikleri doğrultusunda metafor kategorileri oluşturulmuş, uzman görüşlerinden yararlanarak kategorilere metaforlar yerleştirilip, kodlanarak tablolaştırılmıştır. Araştırmacı tarafından uzman görüşleri alınarak tablo tekrar değerlendirilmiş üretilen kategoriler ve kategori bünyesinde bulunan metaforlar, kodlamalar incelenmiş, frekans değerleri göz önünde bulundurularak tablolara yerleştirilmiş ve tabloya son şekli verilmiştir. Araştırmanın güvenilirliğini sağlamlaştırmak için metaforlar ve kategoriler uzmanlar tarafindan incelenmiş, karşılaştırmalar, eşleştirmeler yapılmıştır. Uzmanın yapmış olduğu eşleştirmeler ile hazırlanan tablo karşılaştırılarak görüş birliği sağlanmıştır.Çalışmanın güvenilirliği Milles ve Huberman (1994) uyuşum yüzdesi " $\mathrm{P}=[\mathrm{Na} /(\mathrm{Na}+\mathrm{Nd}) \times 100]$ " "Güvenirlik = görüş birliği / (görüş birliği + görüş ayrıllğı)" formülünden yararlanılarak hesaplanmıştır. Bu durumda "0.93" olarak uyuşum yüzdesi belirlenmiştir. 
Güvenirliğin belirlenmesinde kullanılan uyuşum yüzdesinin $\% 70$ ve üzeri olması çalışmanın güvenirlik yüzdesine ulaşılmış olduğunun göstergesidir (Yıldırım ve Şimşek, 2008). Daha sonra ise elde edilen veriler bilgisayar ortamına aktarılarak 102metaforve 7 kavramsal kategoriyi temsil eden katılımcı sayısı (f) belirlenmiştir.

\section{BULGULAR}

Bu bölümde Eğitim Teknolojisi kavramına ilişkin öğrencilerin ürettikleri metaforlara, metaforların yer aldığı kategorilere ve metaforların frekans değerlerine yer verilmiştir.

Tablo 1

Ĕ̈itim Teknolojisi kavramına ilişkin metaforların frekans değerleri

\begin{tabular}{llllll}
\hline Metafor & f & Metafor & f & Metafor & f \\
\hline Robot & 2 & Yağmur Ormanı & 1 & Ayak & 1 \\
Selfie Çubuğu & 1 & Sebze & 1 & Makyaj & 2 \\
Hizmetçi & 1 & Arkeoloji Kazısı & 1 & Altın & 1 \\
Yapboz & 2 & Eşya & 1 & Rüzgar & 1 \\
Pusula & 1 & Yapay zeka & 1 & Uzuv & 1 \\
Araç & 4 & Lunapark & 2 & Uzaktan Kumanda & 1 \\
Kalem & 1 & Yiyecek & 1 & Kitap & 4 \\
Sonsuzluk & 1 & Bilim adamı & 1 & Geliş̧̧iş ülke & 1 \\
Akıl & 1 & Hediye kutusu & 1 & Çocuk yetiştirme & 1 \\
Fidan & 5 & Tarla & 1 & Pencere & 1 \\
Sanat & 1 & Çizgi Film & 1 & Aksesuar & 1 \\
Navigasyon & 1 & Moda & 1 & Çağ & 1 \\
İnsan & 1 & Bor madeni & 1 & Gökyüzü & 1 \\
Oyun & 3 & Yardımsever insan & 1 & Bitki & 1 \\
Hayat & 1 & Arkadaş & 1 & Aşk & 2 \\
Hayal & 1 & Hava & 1 & Hizmet & 1 \\
Su & 10 & Dünya & 2 & Ray & 1 \\
Fabrika & 1 & El & 1 & Salıncak & 1 \\
Uçak & 1 & Beyin & 3 & Elektrik akımı & 1 \\
Hızlı Tren & 1 & Kaban & 1 & Nefes & 1 \\
Güneş & 7 & Yelpaze & 1 & Uzay & 2 \\
Öğretmen & 1 & Tatlı & 2 & Gübre & 1 \\
Tohum & 1 & İlaç & 2 & Temel organ & 2 \\
Telefon & 1 & Bel kemiği & 2 & Enstrüman & 1 \\
Tuz & 1 & Sindirim sistemi & 1 & Kestirme yol & 1 \\
\hline
\end{tabular}




\begin{tabular}{llllll}
\hline Hizmetli & 1 & Deniz feneri & 1 & Bilgisayar & 1 \\
Yağmur & 1 & Çiçek & 1 & Okul & 1 \\
Pembe kalem & 1 & Ansiklopedi & 1 & Araba & 2 \\
Diyet & 1 & Toprak & 1 & Televizyon & 1 \\
Kadın & 1 & Vitamin & 1 & Değirmen & 1 \\
Tahteravalli & 1 & Harita & 1 & Uyku & 2 \\
Saat & 1 & Flash Disk & 1 & Iş1k & 1 \\
Yemek & 1 & Hemşire & 1 & Kiyafet & 1 \\
Laboratuvar & 1 & Rehber & 1 & Cerrah & 1 \\
\multicolumn{2}{l}{ Toplam:102 Metafor } & & & & \\
\hline
\end{tabular}

Yukarıda verilen tabloda öğretmen adaylarının eğitim teknolojisi kavramına ilişskin üretmiş oldukları metaforlar ve metaforların frekans değerlerine yer verilmiştir. Tabloda öğrencilerin eğitim teknolojisi kavramına ilişkin 102metafor ürettiği görülmektedir. Eğitim teknolojisi kavramına ilişkin metaforlar incelendiğinde öğrenciler tarafından en fazla değinilen kavramın "su" olduğu görülmektedir. Ayrıca öğrencilerin bir kısmı metaforları, harita, yemek, güneş, kıyafet, uyku, beyin, vitamin, kadın, diyet, yağmur, öğretmen, hızlı tren gibi, çiçek, saat, ışık, olarak ifade etmişlerdir.

Tablo2

Ĕ̆itim Teknolojisi kavramına ilişkin kategoriler, metaforlar ve frekansları

\begin{tabular}{|c|c|c|c|}
\hline Kategoriler & Metaforlar & $\begin{array}{l}\text { Metafor } \\
\text { say1s1 }\end{array}$ & $\mathrm{f}$ \\
\hline $\begin{array}{lr}\text { Temel } & \text { gereksinim } \\
\text { sembolü } & \text { olarak } \\
\text { eğitim teknolojisi }\end{array}$ & 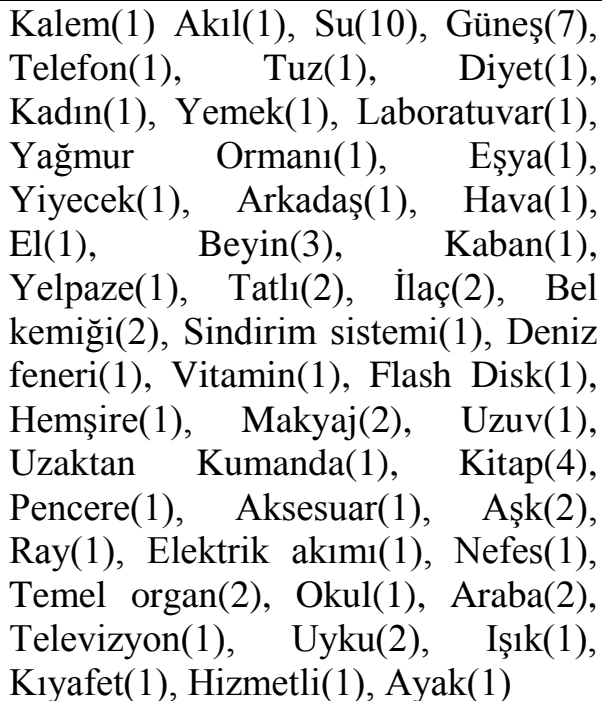 & 46 & 74 \\
\hline
\end{tabular}




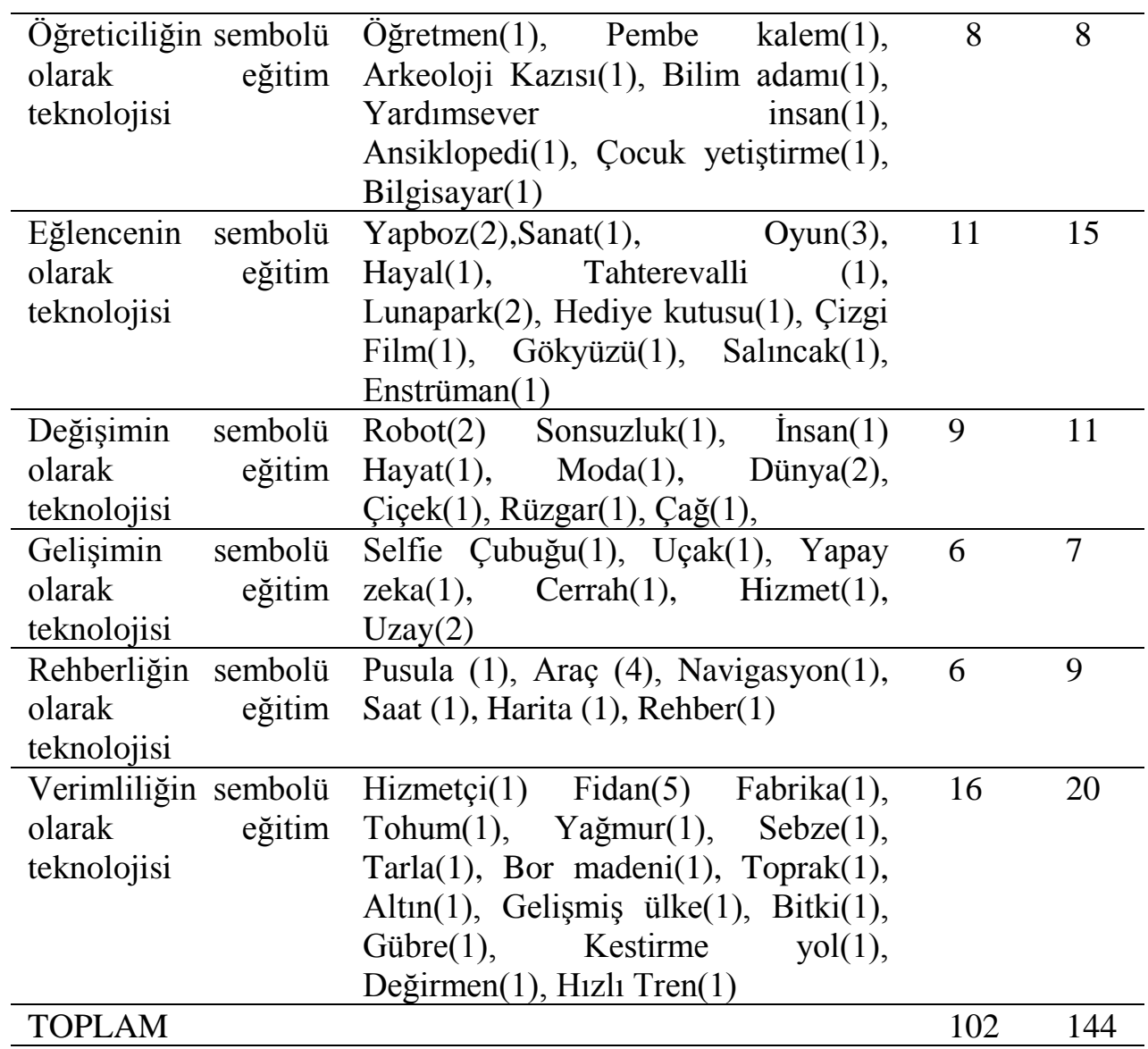

Yukarıda bulunan tablo 2'de öğretmen adaylarının eğitim teknolojisi kavramına yönelik ürettikleri metaforların kategorik hali bulunmaktadır. Yapılan analizler neticesinde elde edilen metaforlar, öğretmen adaylarının yükledikleri anlamlara göre sınıflandırılmış ve frekans değerleri gösterilmiştir. Öğretmen adaylarının yükledikleri anlamlardan yola çıkarak 7 olumlu anlam içeren kategori belirlenmiştir. Metaforlar incelendiğinde102 metaforun olumlu anlam ifade ettiği görülmektedir. Tabloya göre en fazla değinilen ( $\mathrm{f}=74)$ kategori 46 metafordan oluşan temel gereksinim sembolü olarak eğitim teknolojisi kategorisi, en az değinilen kategoriler ise 6 metafordan oluşan gelişimin sembolü olarak eğitim teknolojisi $(\mathrm{f}=6)$ ve rehberliğin sembolü olarak eğitim teknolojisi $(\mathrm{f}=6)$ kategorileridir.

Kategoriler ile ilgili açıklamalar ve öğrenci ifadeleri aşağıda yer almaktadır. 


\section{Temel gereksinim sembolü olarak eğitim teknolojisi}

$\mathrm{Bu}$ kategoride bulunan metaforlar incelendiğinde öne çıkan ortak özelliğin temel ihtiyaç olarak kabul edilmesi, olmazsa olmaz olarak görülmesidir. Öğretmen adayları tarafindan en fazla metaforun üretildiği(46) ve en fazla ögrenci $(\mathrm{f}=74)$ sayısına sahip olan kategoridir. Temel gereksinimler, önemli ihtiyaç ile ilişkilendirilerek "su, güneş, kitap, beyin, el vs." gibi metaforlar öğrenciler tarafından üretilmiştir. Kategoriler içerisinde en çok değinilen metaforları barındıran kategori özelliğini göstermektedir. En fazla değiniline metafor "su" metaforudur.

$\mathrm{Bu}$ kategoriyi oluşturan ve en fazla ögretmen aday sayısına sahip olan metaforların öğretmen adayları tarafından tanımlamaları aşağıdaki örneklerde verilmiştir.

"Eğitim teknolojisi su gibidir, çünkü su nasıl hayatta kalabilmemiz için gerekli ise eğitim teknolojisi de hedeflerin amaca ulamasını sağlamak için o kadar gereklidir. "Ö8

"Eğitim teknolojisi su gibidir, çünkü insanların suya olan ihtiyacı kadar eğitim teknolojisi de ders, eğitim, ögrenci için gereklidir”Ö18

"Eğitim teknolojisi güneş gibidir, çünkü güneş ısı ve ışık kaynağıdır yaşamın temel kaynağıdır. Güneşsiz bir alemin varlı̆ğ mümkün değildir tıpkr eğitim teknolojisiz bir eğitim ortamı gibi"Ö33

"Eğitim teknolojisi beyin gibidir, çünkü beynimiz olmadan yaşayabilmemiz, düşünebilmemiz, anlayabilmemiz mümkün değildir. Eğitim teknolojisi de eğitimin beyni gibidir. Düşünmeyi anlamayı kolaylaştırır. ”Ö116

"Eğitim teknolojisi yiyecek gibidir, çünkü yiyecek yaşamın olmazsa olmazıdır. Ĕ̈itim teknolojisi de ĕgitimin olmazsa olmazıdır”. Ö3

\section{Öğreticiliğin sembolü olarak ĕgitim teknolojisi}

Bu kategoride bulunan metaforlar incelendiğinde öne çıkan ortak özelliğin öğreticilik olduğunu söyleyebiliriz. Öğretim, öğrenme kavramları ile ilişkilendirilerek metaforlar üretilmiştir. Gelişim ve Rehberlik kategorilerinden sonra en az metaforu bulunan (8) ve en az öğretmen aday sayısına sahip ( $\mathrm{f}=8$ ) kategoridir. Bu kategoride öğreticilik ile ilişkilendirilerek "öğretmen, bilim adamı, ansiklopedi, pembe kalem" gibi metaforlar öğretmen adayları tarafından üretilmiştir.

Kategoriyi oluşturan metaforların öğretmen adayları tarafından tanımlamaları aşağıdaki örneklerde verilmiştir. 
"Eğitim teknolojisi öğretmen gibidir, çünkü öğretmek, bilgi vermek için vardır." Ö27

"Eğitim teknolojisi bilim adamı gibidir, çünkü amacı çalışmak, öğrenmek, ögretmektir." Ö39

"Eğitim teknolojisi ansiklopedi gibidir, nasıl ki bilmediğimiz bir şey hakkında ansiklopediden yararlanıp ögrenebiliyorsak ĕgitim teknolojisi aracılı̆̆lyla da să̆glkll ögrenmeler gerçekleştirebiliyoruz. "Ö78

"Eğitim teknolojisi, pembe kalem gibidir, çünkü pembe kalem ile yazılan yazı oldukça dikkat çeker öğrenilmesi kolay, unutulması zordur. Eğitimde kullanılan eğitim teknolojileri de böyledir. "Ö55

\section{Ĕ̆lencenin sembolü olarak ĕgitim teknolojisi}

$\mathrm{Bu}$ kategoride bulunan metaforlar incelendiğinde öne çıkan ortak özelliğin eğlendiricilik olduğu, eğitim teknolojisinin eğlence ile ilişkilendirildiğini söyleyebiliriz. Kategoride öğretmen adaylarının ortak düşüncesi eğitim teknolojisi kavramının eğlendirerek öğretici yapısı ile renkli bir eğitimöğretimin varlığını sağlayıcı niteliğe sahip olma durumudur. Temel gereksinimin sembolü olarak eğitim teknolojisi ve verimliliğin sembolü olarak eğitim teknolojisi kategorilerinden sonra en fazla metafora (11) ve en fazla öğretmen aday sayısına $(\mathrm{f}=15)$ sahip 3. kategoridir. Kategoride eğlendiricilik ile ilişkilendirilerek "çizgi film, lunapark, salıncak,enstrüman" gibi metaforlar öğretmen adayları tarafindan üretilmiştir.

Kategoriyi oluşturan metaforların öğretmen adayları tarafından tanımlamaları aşağıdaki örneklerde verilmiştir.

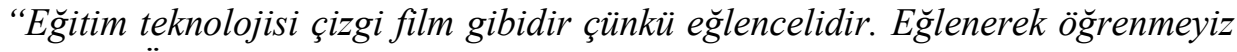
sağlar. "Ö5

"Eğitim teknolojisi lunapark gibidir, çünkü çok renkli çeşit çeşit duyularımıza hitap eden bizi eğlendiren araçlarla doludur". Ö17

"Eğitim teknolojisi salıncak gibidir, çünkü salıncakta sallanirken rahatlarsın, eğlenirsin. Eğitimde de teknoloji kullanımı, eğitim teknolojisinden yaralanarak bir ders anlatımı eğlenceli olur "Ö91

"Eğitim teknolojisi enstrüman gibidir,çünkü müzik üretmek zevkli bir iştir. Ĕgitim teknolojisinden yararlanarak bilgi üretmek gibi.”Ö87

\section{Değişimin sembolü olarak eğitim teknolojisi}

$\mathrm{Bu}$ kategoride bulunan metaforlar incelendiğinde öne çıkan ortak özelliğin değişim olduğunu söyleyebiliriz. Burada kastedilen eğitim teknolojisi kavramının değişimi sağlayıcı özelliğe sahip olma durumudur. Temel gereksinimin sembolü olarak eğitim teknolojisi, verimliliğin sembolü olarak 
eğitim teknolojisi ve eğlencenin sembolü olarak eğitim teknolojisi kategorilerinden sonra en fazla metafora (9) ve en fazla öğretmen aday sayısına ( $\mathrm{f}=11$ )sahip4. kategoridir. Bu kategoride değişim ile ilişkilendirilerek "moda, insan, çağ, rüzgar" gibi metaforlar öğretmen adayları tarafından üretilmiştir.

Kategoriyi oluşturan metaforların öğretmen adayları tarafından tanımlamaları aşağıdaki örneklerde verilmiştir.

"Eğitim teknolojisi moda gibidir, çünkü sürekli değişmektedir, yeni şeylerin üretilmesi ile farklıllklar yaratılmaktadır." Ö94

"Ĕ̈itim teknolojisi insan gibidir, çünkü nasıl ki insanlar olaylar durumlar karşında değişir farkl farkll davranırsa eğitim teknolojisi de çeşitli değişkenlere göre farklılaşır." Ö76

"Eğitim teknolojisi çağ gibidir, çünkü ortaya çıkan eğitim teknolojileri var olan eğitim çă̆ını değişstirir, eski alışkanlıkları değiştirir, yeni bir dönemi açar." Ö63

"Eğitim teknolojisi rüzgar gibidir, çünkü estiği yerin iklimini değiştirir. Meltem rüzgarı nasıl bir ılımanlaştırıcl, rahatlatıcı etkiye sahipse eğitim teknolojisi de eğitim için öyledir. "Ö29

\section{Gelişimin sembolü olarak eğitim teknolojisi}

$\mathrm{Bu}$ kategoride bulunan metaforlar incelendiğinde öne çıkan ortak özelliğin gelişim olduğunu söyleyebiliriz. Burada kastedilen eğitim teknolojisi kavramının gelişimi sağlayıcı özelliğe sahip olma durumudur. Eğitim teknolojisi kavramının gelişmeye imkan tanıyıcı bir nitelikte olduğu düşünülerek, gelişim ile ilişkilendirilip metaforlar öğrenciler tarafından üretilmiştir. Rehberliğin sembolü olarak eğitim teknolojisi kategorisi ile birlik en az metafora sahip olan (6) kategoridir. Aynı zamanda en az öğrenci sayısına (f=7) sahip kategori özelliği göstermektedir. Kategoride gelişim ile ilişkilendirilerek "hizmet, uzay, cerrah, yapay zeka" gibi metaforlar öğretmen adayları tarafından üretilmiştir.

Kategoriyi oluşturan metaforların öğretmen adayları tarafından tanımlamaları aşağıdaki örneklerde verilmiştir.

"Eğitim teknolojisi hizmet gibidir, çünkü bir yere ne kadar çok hizmet uygularsan o kadar çok gelişim gösterir. Eğitimde de ne kadar çok eğitim teknolojilerinden yararlanirsan o kadar gelişim kaydedersin. "Ö46

"Ĕ̈itim teknolojisi cerrah gibidir, çünkü bir cerrah ameliyat yapa yapa gelişim kaydeder eğitimde eğitim teknolojisinden yararlanarak gelişim kaydeder."Ö51

"Eğitim teknolojisi yapay zeka gibidir, çünkü insanlı̆̆a faydalı bir gelişimi sağlayabilecek özelliğe sahiptir. ”Ö14 
"Eğitim teknolojisi uzay gibidir, çünkü çok geniştir sonsuzdur araştırdıkça yeni şeyler ürettikçe gelişmeler kaydedersin eğitim teknolojisi de öyledir. ”Ö131

\section{Rehberliğin sembolü olarak eğitim teknolojisi}

$\mathrm{Bu}$ kategoride bulunan metaforlar incelendiğinde öne çıkan ortak özelliğin rehberlik edicilik olduğunu söyleyebiliriz. Burada kastedilen eğitim teknolojisi kavramının rehberlik edici nitelikte olup yol gösterici durumunda olmasıdır. Gelişimin sembolü olarak eğitim teknolojisi kategorisi ile birlikte en az metafora sahip olan 6.kategoridir. Kategoride metafor üreten $(\mathrm{f}=9)$ öğrenci bulunmaktadır. Kategoride rehberlik ile ilişkilendirilerek "pusula, rehber, harita, navigasyon, araç" gibi metaforlar öğretmen adayları tarafından üretilmiştir.

Kategoriyi oluşturan metaforların öğretmen adayları tarafindan tanımlamaları aşağıdaki örneklerde verilmiştir.

"Ĕ̈itim teknolojisi araç gibidir, çünkü eğitim teknolojisi olmadan insan eğitimdeki teknolojik yenilikleri ve gelişmelerden haberdar olamaz onlar tanıyamaz, bilemez." Ö45

"Eğitim teknolojisi rehber gibidir, çünkü rehber sayesinde bilmediğimiz şeyler ile ilgili bilgi sahibi oluruz ve ona göre hareket ederiz."

"Eğitim teknolojisi harita gibidir, çünkü nerede olduğunu ne yapman gerektiği ile ilgili sana yol gösterir. "Ö94

"Eğitim teknolojisi pusula gibidir, çünkü kaybolmana müsaade etmez ve istenilen yere seni ulaştırır. Eğitim teknoloji de öyledir. ”Ö2

\section{Verimliliğin sembolü olarak eğitim teknolojisi}

Kategoride bulunan metaforlar incelendiğinde öne çıkan ortak özelliğin verimlilik olduğunu söyleyebiliriz. Burada kastedilen eğitim teknolojisi kavramının verimliliği sağlayıcı özelliklere sahip olma durumudur. Verimliliğin sembolü olarak eğitim teknolojisi kategorisi temel gereksinim sembolü olarak eğitim teknolojisi kategorisinden sonra en fazla metafora (16) ve en fazla ögretmen aday sayısına $(\mathrm{f}=20)$ sahip olan kategoridir.Kategoride verimlilik ile ilişkilendirilerek "tohum, fabrika, değirmen, altın" gibi metaforlar öğretmen adayları tarafından üretilmiştir.

Kategoriyi oluşturan metaforların öğrenciler tarafindan tanımlamaları aşağıdaki örneklerde verilmiştir.

"Ĕ̈itim teknolojisi altın gibidir, çünkü altın gibi değerlidir. Getirisi vardır. Ihtiyaçların karşılanmasına yardım eden yapıdadır. ”Ö39

"Eğitim teknolojisi tohum gibidir, çünkü bereketlidir birçok alanda, konuda kullanabiliriz. İhtiyaçlarımızı karşılar. ”Ö56 
"Ĕgitim teknolojisi fabrika gibidir, çünkü eğitim teknolojisi sayesinde de bolca bilgi üretilir. "Ö11

"Ĕgitim teknolojisi değirmen gibidir, çünkü un değirmende üretilir bilgi de eğitim teknolojisi ile elde edilir. "Ö83

\section{SONUÇ VE ÖNERÍLER}

Teknoloji çağı olarak adlandırılan yüzyılda teknolojik getirilerin eğitim sektörüne yansıması, eğitim- ögretim boyutunda kendine önemli bir yer elde etmesi, yaygın bir şekilde kullanım alanına sahip olması öğrencilerin konuya bakış açılarının, konu ile ilgili tutum ve düşüncelerinin belirlenmesini zorunlu kılmıştır (Yavuz ve Coşkun, 2008). Yürütülen bu çalışmada da zorunluluktan hareket edilerek eğitim öğretimin önemli bir paydaşı olan, eğitim öğretim faaliyetlerine önemli ölçüde yön veren sınıf öğretmen adaylarının "eğitim teknolojisi" kavramına yönelik sahip oldukları algıları metaforlar aracılığıyla ortaya çıkarmak amaçlanmıştır. Çalışmada öğretmen adaylarının kavram ile ilgili olarak "hava, su, güneş, lunapark, rüzgar, kitap, beyin, el, kadın, aşk vd."102 metafor ürettikleri görülmektedir. Araştırma bulguları, öğretmen adaylarının eğitim teknolojisi kavramına ilişkin metaforlarının"Temel gereksinim sembolü olarak eğitim teknolojisi”( $(\mathrm{f}=74)$, “Öğreticiliğin sembolü olarak eğitim teknolojisi" $(\mathrm{f}=8)$, "Eğlencenin sembolü olarak eğitim teknolojisi"( $(\mathrm{f}=15)$, "Değişimin sembolü olarak eğitim teknolojisi” $(\mathrm{f}=11)$, "Gelişimin sembolü olarak eğitim teknolojisi”" $(\mathrm{f}=7)$, "Rehberliğin sembolü olarak eğitim teknolojisi”’(f=9), "Verimliliğin sembolü olarak eğitim teknolojisi" $(\mathrm{f}=21)$ olarak 7 kategoride yer aldığını göstermektedir. Literatür incelendiğinde çalışma bulgularını destekleyen kategorilerin teknoloji ve internet kavramlarına yönelik yapılan metaforik çalışmalarla benzediği görülmektedir (Erdoğan ve Gök 2012; Şahin ve Baturay, 2013; Fidan, 2014; Karaçam ve Aydın, 2014; Durukan, Hacıŏlu ve Dönmez Usta, 2016).

Temel gereksinim sembolü olarak eğitim teknolojisi kategorisi, en fazla metaforun üretildiği (46) ve en fazla öğretmen aday ( $\mathrm{f}=74$ ) sayısına sahip olan kategoridir. Kategoride temel gereksinim, vazgeçilemez ihtiyaç ile ilişkilendirilerek metaforlar üretilmiştir. Kategori dâhilinde öğretmen adayları eğitim öğretim faaliyeti için eğitim teknolojisini vazgeçilmez olarak görmekte, sağlıklı, kalıcı, etkili öğrenmelerin gerçekleştirilmesi adına olmazsa olmaz olarak kabul etmektedir. Teknoloji metaforunun incelendiği araştırmalarda eğitim teknoloji kavramında olduğu gibi kavram temel ihtiyaç, gereksinim olarak düşünülüp metaforlar üretilmiştir. Erdoğan ve Gök'ün (2012) teknoloji 
kavramına yönelik algıları metaforlar aracılığıyla belirlemeye çalıştıkları çalışmalarına benzer olarak eğitim teknolojisi kavramı da temel bir gereksinim, hayati bir ihtiyaç olarak kabul edilerek kategori bünyesinde en fazla "Su" $(\mathrm{f}=10)$ metaforu ile ilişkilendirilerek ifade edilmiştir. Fidan'ın (2014) yapmış olduğu çalışmada teknoloji kavramına ilişkin geliştirilen metaforların alt kategorilerinden bir tanesi de "temel ihtiyaç" kategorisidir. Kategoride en fazla değinilen metaforlar yürütülen çalışmada olduğu gibi "su ve güneş" metaforları olmuştur.

Öğreticiliğin sembolü olarak eğitim teknolojisi kategorisi, en az metaforu (8) bulunan üçüncü, en az öğretmen aday sayısına sahip ikinci $(\mathrm{f}=8)$ kategoridir. $\mathrm{Bu}$ kategoride eğitim teknolojisinin öğreticilik, öğrenmeye kaynaklık etme, öğrenmeyi sağlama durumları göz önüne alınarak öğretmen adayları tarafından metaforlar üretilmiş̧ir. Kategori dahilinde çalışma bulgularını destekleyen sonuçlar Durukan, Hacıŏlu ve Dönmez Usta'nın (2016) bilgisayar ve öğretim teknolojileri öğretmen adaylarının teknolojik algılarını belirlemeye çalıştıkları çalışma sonuçları ile benzerlik göstermektedir. Çalışmada teknoloji kavramının bilgi kaynağı/öğretme alt kategorisi kapsamında öğreticilik görevini yürüttüğü, öğrenmeye kaynaklık ettiği belirtilmiştir. Yürütülen çalışmada da sınıf ögretmeni adayları tarafından eğitim teknolojisi kavramının bilgiye kaynaklık etme, öğreticilik yönü ile algılanıp, değerlendirilerek metaforlar ürettiği görülmektedir. Eğlencenin sembolü olarak eğitim teknolojisi kategorisi, en fazla metafora (11) ve en fazla öğretmen aday sayısına ( $\mathrm{f}=15)$ sahip üçüncü kategoridir. Kategoride, eğitim teknolojisinin eğitim ortamı, eğitim faaliyeti için önemine dikkat çekilerek, eğitim faaliyetlerinde eğlendirerek öğreticiliğin öğrenme üzerindeki olumlu etkisi ifade edilmeye çalışılmışırı. Kategori bünyesindeki metaforlardan, öğretmen adayı ifadelerinden hareketle eğitim teknolojisinin öğrencileri motive ederek, eğitim sürecine eğlenceli, zevkli bir yap1 kazandırdığı anlaşılmaktadır. Bulguları destekler şekilde Koşar (2002) "eğitim teknolojisi” kavramını öğrenmeye teşvik eden, öğrenmeyi kolaylaştırma adına öğrenciyi motive eden araç gereçlerin işe koşularak denenmesi ve geliştirilmesi şeklinde yorumlamıştır. Eğlendirerek öğreten, eğitim öğretim faaliyetlerine renkli bir hava katan, sıkıcılığı durağanlığ 1 azaltarak öğrenmeyi kolaylaştıran araç gereçler olarak kavramın değerlendirilmesi tanımla örtüşmektedir.

Değişimin sembolü olarak eğitim teknolojisi kategorisi en fazla metafora sahip dördüncü (9) ve en fazla öğretmen aday sayısına ( $f=11$ ) sahip dördüncü kategoridir. Kategoride eğitim teknolojisi değişimi sağlayıcı özellikleri barındıran bir yapıya sahip olarak görülmektedir. Kategori bünyesindeki metaforları üreten öğretmen adayı ifadelerinden eğitim teknolojisinin, eğitim öğretim boyutunda değişimlerin yaşanmasına katkı sağlayıcı özellikte olduğu anlaşılmaktadır. Olumlu yapıda değişimlerin ve yeniliklerin, zamana uygun 
hareket etmenin eğitim faaliyetlerindeki önemine dikkat çekilmektedir. Çağa etki eden teknolojilerin eğitim sektörüne yansımaları ve bu değişimlerin durağan olmadığı, farklı değişimleri de beraberinde getireceği ifade edilmeye çalışılmıştır. Bulgular, Fidan'ın (2014) öğretmen adaylarının teknoloji ve sosyal ağ kavramlarına ilişkin metaforik algılarını belirlemeye çalıştığı çalışmasında "değişim-gelişim" kategorisi bulguları ile benzerlik göstermektedir. Gelişimin sembolü olarak eğitim teknolojisi kategorisi en az metafor sayısına sahip kategorilerden biri olup (6) en az öğretmen aday sayısına (f=7) sahip kategoridir. Kategoriden eğitim teknolojisi kavramının gelişim yolunda önemli bir araç olarak görüldüğü anlaşılmaktadır. Gelişimin sağlanması ve gelişmenin sürekliliği adına eğitim öğretim faaliyetlerinde eğitim teknolojisinden yararlanmanın önemine değinilmiştir. Çalışma bulguları Fidan (2014) ile benzerlik göstermektedir. Rehberliğin sembolü olarak eğitim teknolojisi kategorisi en az metafora sahip (6) kategorilerden biri olup, en az öğretmen aday sayısına sahip ( $\mathrm{f}=9$ ) üçüncü kategoridir. Rehberliğin sembolü olarak eğitim teknolojisi kategorisinde kavram yol gösterici, eğitim öğretim faaliyetleri için dayanak, nasıl hareket edileceği ile ilgili ışık tutan bir pusula konumda değerlendirilmiştir. Denizde kaybolan bir gemiye pusula nasıl yardımcı olup, onu kaybolmaktan belki de yok olmaktan kurtarıyorsa eğitim öğretim faaliyetlerinde eğitim teknolojisinin aynı derecede bir fonksiyonu olduğu ifade edilmeye çalışılmıştır. Verimliliğin sembolü olarak eğitim teknolojisi kategorisi en fazla metafor sayısına (16) ve en fazla öğretmen aday sayısına ( $\mathrm{f}=20$ ) sahip ikinci kategoridir. Kategoriden eğitim teknolojisinin ürün oluşumunda önemli işleve sahip olduğu, verimliliğin sağlanması noktasında dikkat çekici bir yapıda olduğu, eğitim teknolojisinin eğitimin hedeflerine ulaşmasında verimliliği arttırıcı bir yapı kazandırdığı anlaşılmaktadır. Eğitim teknolojilerinden yararlanma ile ilgili yapılan birçok çalışma sonuçları yürütülen çalışma sonuçlarını destekler niteliktedir. Çalışmalarda öğrencilerin eğitimde teknoloji kullanımına ve eğitim teknolojisine bakış açılarının pozitif olduğu, olumlu tutum ve davranış geliştirdikleri görülmektedir (Akpınar, Aktamış ve Ergin, 2005; Yavuz ve Coşkun, 2008; Y1lmaz, 2005).

Sonuç olarak sınıf öğretmeni adaylarının "eğitim teknolojisi" kavramına yönelik olumlu görüş ve algılarının göstergesi olan metaforlar ürettikleri görülmektedir. Sınıf öğretmeni adayları tarafından "eğitim teknolojisi" kavramı oldukça önemli kabul edilmekte, temel bir gereksinim, yararlanılması gereken zaruri bir öğe, eğlenirken öğrenmeyi sağlayan, gelişim ve değişimi destekleyen, rehberlik ederek sağlıklı öğrenmeler gerçekleştirmede yardımcı olan vazgeçilmez ihtiyaç olarak değerlendirilmektedir. Öğretim teknolojileri ve materyal tasarımı dersini almış olan sınıf öğretmeni adaylarının "eğitim teknolojisi" ile ilgili olarak olumsuz bir metafor üretmedikleri görülmüş olup aksine öğretmen adaylarının büyük çoğunluğu tarafından zaruri bir ihtiyaç 
olarak görülmesi, değerlendirilmesi dersin beklentilerini karşılar bir sonuç olarak değerlendirilebilir. Ayrıca öğretmen adaylarının eğitim teknolojisini sadece görsel-işitsel araçlar bazında algılamadıkları da görülmektedir. Eğitim teknolojisi insan öğrenmesi olgusunun tüm yönlerini içeren problemleri sistematik olarak analiz etmek, bunlara çözümler geliştirmek üzere ilgili tüm unsurları işe koşarak uygun tasarımlar geliştiren uygulayan yöneten bir süreçtir (Alkan, 2011: 15). Öğretmen adaylarının kavrama yönelik algılarının ifadeyi destekler nitelikte olduğunu söyleyebiliriz.

\section{Öneriler}

Sınıf öğretmeni adaylarının "eğitim teknolojisi" kavramına ilişkin metaforik algıları incelendiğinde, benzer çalışma bulguları ile ilişkilendirilerek değerlendirmeler yapıldığında eğitim teknolojisi kavramının eğitim öğretim sürecindeki etkililiği ve önemi anlaşılmaktadır. Buradan hareketle eğitim teknolojinin öğretim sürecinde etkin ve sağlıklı kullanımının sağliklı öğrenme yaşantılarının gerçekleşmesini sağlayacağ 1 düşünülmektedir. Öğretmen adaylarının eğitim öğretim faaliyetlerinde eğitim teknolojilerinden, teknolojik araç gereçlerden yararlanmalarına daha fazla olanak sağlanabilir. Fakülteler, okullar bu doğrultuda iyileştirilebilir. Öğretim üyeleri tarafindan eğitim teknolojilerinden yararlanılarak yapılan öğretim uygulamaları örnek teşkil ederek öğrencileri eğitim teknolojilerini kullanmaya teşvik edici olabilir. Çalışma bulgularından, üretilen metaforlardan hareket edilerek konu ile ilgili likert tipi bir ölçek ve görüşme formu hazırlanabilir. Öğrencilerin, öğretmenlerin, akademisyenlerin konu ile ilgili bakış açılarını derinlemesine değerlendirme adına görüşmeler yapılabilir. Araştırmanın benzerleri farklı üniversitelerde, farklı bölümlerde öğrenim gören öğrencilerde, farklı kurumlarda çalışan öğretmenlerde, üniversitelerde görev yapan akademisyenlerden oluşan gruplar içinde de denenebilir. 


\section{KAYNAKÇA}

Akpınar, E., Aktamış, H. \& Ergin, Ö. (2005). Fen Bilgisi Dersinde Eğitim Teknolojisi Kullanılmasına İlișkin Öğrenci Görüșleri. TheTurkish Online Journal of Educational Technology - TOJET, 4-1, Article 12.

Alkan, C. (2011). Eğitim teknolojisi. Ankara: Anı.

Aydın, F. (2010). Ortaöğretim Öğrencilerinin Coğrafya Kavramına İlişkin Sahip Oldukları Metaforlar. Kuram ve Uygulamada Eğitim Bilimler Dergisi, 10(3),1293-1322.

Aydın, F. (2011). Üniversite Öğrencilerinin Çevre Kavramına Yönelik Metaforik Algıları. Doğu Coğrafya Dergisi, 16(26), 25-44.

Aydoğdu, E. (2008). İlköğretim Okullarındaki Öğrenci Ve Ö̆̆retmenlerin Sahip Oldukları Okul Alglları İle İdeal Okul Algılarının Metaforlar (Mecazlar) Yardımıyla Analizi. Osmangazi Üniversitesi/Fen Bilimleri Enstitüsü, Eskişehir.

Büyüköztürk, Ş., Kılıç Çakmak, E., Akgün, Ö.E., Karadeniz, Ş. \& Demirel, F. (2008). Bilimsel Araştırma Yöntemleri, Pegem Yayınları, Ankara.

Cerit, Y. (2008). Öğretmen Kavramı İle İlgili Metaforlara İlişkin Öğrenci, Öğretmen Ve Yöneticilerin Görüşleri. Türk Eğitim Bilimleri Dergisi, 6(4),693-712.

Durukan, Ü. G., Hacioğlu, Y. \& Dönmez Usta, N. (2016). Bilgisayar ve Öğretim Teknolojileri Öğretmeni Adaylarının Teknoloji Algıları. Bilgisayar ve Eğitim Araştırmaları Dergisi, 4(7) 24-46.

Eraslan, L. (2011). Sosyolojik Metaforlar. Akademik Bakış Dergisi, 27, 1-22.

Erdemir, N., Bakırcı, H. \& Eyduran, E. (2009). Ö ğretmen Adaylarının Eğitimde Teknolojiyi Kullanabilme Özgüvenlerinin Tespiti. Türk Fen Eğitimi Dergisi, 6(3),99-108.

Erdoğan, T. \& Gök, B. (2008). Sınıf Öğretmeni Adaylarının Teknoloji Kavramına İlişkin Algılarının Metafor Analizi Yoluyla İncelenmesi. 
İn Proceedings of 8th International EducationalTechnology Conference (pp.1071-1077). Eskişehir, Turkey.

Fidan, M. (2014). Öğretmen Adaylarının Teknoloji ve Sosyal A $\breve{g}$ Kavramlarına İlişkin Metaforik Algıları. TheJournal of Academic Social Science Studies İnternational Journal of Social Science, 25(1), 483-496.

Geçit, Y. \& Gencer, G. (2011). Sınıf Öğretmenliği 1. Sınıf Öğrencilerinin Coğrafya Algılarının Metafor Yoluyla Belirlenmesi (Rize Üniversitesi Örneği). Marmara Coğrafya Dergisi,23,1-19.

Hacıfazlığulu, Ö., Karadeniz, Ş. \& Dalgıç, G. (2011). Okul Yöneticilerinin Teknoloji Liderliğine İlişkin Algıları: Metafor Analizi Örneği. Eğitim Bilimleri Araştırmaları Dergisi, 1(1), 97-121.

Kara, A. \& Uysal, G. (2015). Ortaokul Öğretmenlerinin Öğrenmeye İlişkin Tutumlarının Sınıf Koşulları Açısından İncelenmesi. The Journal of Academic Social Science Studies (JASSS),41. 35-53.

Karaçam, S., Aydın, F., (2014) Ortaokul Öğrencilerinin Teknoloji Kavramına İlişkin Algılarının Metafor Analizi. Gaziantep Üniversitesi, University Journal of Social Sciences,1(2), 545-572.

Kıral, E. (2015). Öğretmen Adaylarının Algılarına Göre Öğretmen Metaforları. Adnan Menderes Üniversitesi Eğitim Fakültesi Eğitim Bilimleri Dergisi, 6(1), 57-65.

Koşar, E. (2002). Öğretim Teknolojileri ve Materyal Geliştirme, Ezgi Kitapevi, Bursa.

Lakoff, G. \& Johnson, M. (2003). Metaphors We Live By. The University of Chicago Press. London.

Levine, P.M. (2005). Metaphors and İmages of Classrooms. ERIC Document: EJ724893.

Miles, M.B. \& Huberman, A.M. (1994). Qualitative Data Analysis. Thousand Oaks, CA: Sage.

Ortony, A. (1993). Metaphor, Language And Thought, In A. Ortony (Ed.), Metaphor And Tought. Cambridge: Cambridge University Press. 
Oxford, R. L.,Tomlinson, S., Barcelos, A., Harrington, C., Lavine, R. Z., Saleh, A., \& Longhini, A. (1998). Clashing Metaphors About Classroom Teachers: Toward a Systematic Typology For The Language Teaching Field. System, 26,3-50.

Öksüz, Y., Demir, E. \& İci, A. (2016). Öğretmenlerin Dijital Okuryazarlık Kavramına İlişkin Metaforlarının İncelenmesi. İnternational Journal of Social Science, 50, 387-396.

Parın, K. (2017). Metaforlar, Hayat, Anlam ve Dil. Söylem Filoloji Dergisi, 2(3), 149-151.

Saban, A. (2009). Öğretmen Adaylarının Öğrenci Kavramına İlişkin Sahip Olduğu Zihinsel İmgeler. Türk Eğitim Bilimleri Dergisi, 7(2), 281-326.

Seferoğlu, S. S. (2009, Şubat). İlköğretim Okullarında Teknoloji Kullanımı ve Yöneticilerin Bakış Açıları. Akademik Bilişìm Konferansında Sunulan Bildiri. Harran Üniversitesi, Şanlıurfa. Erişim Adresi: https://ab.org.tr/ab09/kitap/seferoglu_AB09.pdf

Semerci, Ç. (2007). Program Geliştirme Kavramına İlişsin Metaforlarla Yeni İlköğretim Programlarına Farklı Bir Bakış. Cumhuriyet Üniversitesi Sosyal Bilimler Dergisi, 31(2),125-140.

Seung, E., Park, S. \& Narayan, R. (2011). Exploring Elementary Pre-Service Teachers' Beliefs About Science Teaching And Learning As Revealed İn Their Metaphor Writing. J Sci Educ Technol, 20,703-714.

Stofflett, R. T. (1996). Metaphor Development By Secondary Teachers Enrolled İn Graduate Teacher Education. Teaching and Education, 12(6),572-589.

Şahin, Ş., \& Baturay, M. H. (2013). Ortaöğretim Öğrencilerinin İnternet Kavramına İlişkin Algılarının Değerlendirilmesi: Bir Metafor Analizi Çalışması. Kastamonu Eğitim Dergisi,21(1), 177-192.

Şimşek, A., Özdamar, N., Becit, G., Kılıçer, K., Akbulut, Y. \& Yıldırım, Y. (2008). Türkiye'deki Eğitim Teknolojisi Araştırmalarında Güncel Eğilimler. Selçuk Üniversitesi Sosyal Bilimler Dergisi,19, 439-458. 
Topçu, Z. \& Türk, M. S. (2016). Dijital Çağ Okuryazarlığı Bağlamında Yeni Medya Becerileri. Yeni Türkiye, 89,459-466.

Uyan Dur, B. İ. (2016). Metafor ve Ekslibris. Uluslararası Eks-libris Dergisi, 3(5),122-128.

Ünsal, S., Korkmaz, F. \& Çetin, A. (2016). Lise Öğrencilerinin "Felsefe" Kavramına Yönelik Metafor Algilarının İncelenmesi. Abant İzzet Baysal Üniversitesi Eğitim Fakültesi Dergisi, 16(3), 1047-1064.

Windschitl, M. (2002). İnquiry Projects İn ScienceTeacher Education: What Can İnvestigative Experiences Reveal About Teacher Thinking And Eventual Classroom Pratice?. Science Teacher Education, 87,112-143.

Wulf, A. \& Dudis, P. (2005). Body Partitioning İn ASL Metaphorical Blends, Sign Language Studies, 5(3), 317-332.

Yanpar, T. (2007). Öğretim Teknolojileri ve Materyal tasarımı. Anı Yayıncılık, Ankara.

Yavuz, S. \& Coşkun, A. E. (2008). Sınıf Öğretmenliği Öğrencilerinin Eğitimde Teknoloji Kullanımına İlişkin Tutum ve Düşünceleri. Hacettepe Üniversitesi Eğitim Fakültesi Dergisi, 34, 276-286.

Yıldırım, A. \& Şimşek, H. (2008). Sosyal Bilimlerde Nitel Araştırma Yöntemleri. Seçkin Yayıncılık, Ankara.

Yılmaz, M. (2005). İlköğretim 7. Sınıflarda Simetri Konusunun Öğretimde Ĕgitim Teknolojilerinin Başarı ve Tutuma Etkisi. Marmara Üniversitesi/Eğitim Bilimleri Enstitüsü, İstanbul. 